\title{
Notes on the presence of mustelus sinusmexicanus and hexanchus nakamurai (chondrichthyes: elasmobranchii) in mexican waters
}

\begin{abstract}
The taxonomy and distribution of 2 deep water sharks, Mustelus sinusmexicanus and Hexanchus nakamurai, is discussed here on the basis of 3 specimens from the Gulf of Mexico. Both species aredistributed in the area; however, they are rarely found in ichthyological collections as they are seldomcaught and due to the challenge of curating such large specimens. Thus, this is the first time that GulfSmooth hound and Bigeye Sixgill shark specimens have been curated in a Mexican ichthyologicalcollection, confirming its presence in México.
\end{abstract}

Keywords: New documented records, Hexanchidae, Triakidae, Mexican sharks, Mustelus sinusmexicanus, Hexanchus nakamurai
Volume 5 Issue 5 - 2017

\author{
Adri n F Gonzalez-Acosta,' Rocio Rodiles- \\ Hernandez, ${ }^{2}$ Alfonso Angel Gonzalez-Diaz, ${ }^{2}$ \\ Manuel Mendoza-Carranza ${ }^{3}$ \\ 'Departamento de Pesquer \\ ${ }^{2}$ Departamento de Conservaci \\ ${ }^{3}$ Departamento de Ciencias de la Sustentabilidad, El Colegio de \\ la Frontera Sur, Mexico
}

Correspondence: Adrián F. González-Acosta, Instituto Politécnico Nacional- Centro Interdisciplinario de Ciencias Marinas, México, Tel: 0I-6|2-1225366; Fax: 0|-6|2-|225322; Email aacosta@ipn.mx

Received: April 27, 2017 | Published: May II, 2017

\section{Introduction}

Selachii comprise a taxon of particular interest for their unique biology, ecology, and behavior; but, intensive fisheries have been reduced dramatically their abundances. ${ }^{1}$ Thus, it is imperative that we taxonomically verify any reports and curate samples of the specimens in the corresponding reference collections. In Mexico, Selachii or sharks are represented by 109 species, which in turn constitute $30 \%$ of the world's species richness. ${ }^{2}$

In this study, we present information regarding the taxonomic characteristics and distribution of Gulf Smooth hound (Triakidae) and Bigeye Sixgill sharks (Hexanchidae) based on the examination of three specimens from the Gulf of Mexico. While both species are distributed in the area, very few are included in reference collections ${ }^{3,4}$ this is due to the rarity of capturing them and the difficulty of curating such large samples.

\section{Materials and methods}

Three specimens of the 2 species reported here were caught by the commercial fishery using bottom long lines near the Campeche Bank in Mexico. These specimens were deposited and cataloged in the ichthyology collection at El Colegio de la Frontera Sur (ECOSC). The specimens were identified following the relevant literature. ${ }^{2,5-11}$ Additionally, biometrics were recorded for each specimen which follow to Ebert et al. ${ }^{9}$ and Heemstra ${ }^{10}$ with some modifications and additions based on the morphology of the organisms examined (Table 1). The nomenclature and taxonomic arrangement are after Page et al. ${ }^{12}$

\section{Description}

We identified a total of 2 genera corresponding to an equal number of families and orders, which were described as follows:

\section{Taxonomy summary}

Class: Chondrichthyes

Subclass: Elasmobranchii

Order: Carcharhiniformes

\section{Family: Triakidae}

Genus Mustelus Linck 1790

The genus Mustelus includes 27 species distributed in tropical, subtropical, and temperate climates of the world's oceans, $, 7,7,8,9$ representing $33.3 \%$ (nine) of the species in Mexican waters. ${ }^{2,13}$ Mustelus sinusmexicanus Heemstra, 1997(Figure 1,Table 1).

a. Common name: Cazón del Golfo (Spa.), Gulf Smooth hound

b. Material examined:Two eviscerated, sexually mature specimens, 1 male (ECOSC 7471-1; $800 \mathrm{~mm}$ TL, 1,100 g) and 1 female (ECOSC 7471-2; 1,092 mm TL, 3,500 g). Both specimens were caught at $48.6 \mathrm{~km}$ north of the San Pedro Port, Centla, Tabasco, Mexico, near of the Campeche Canyon $\left(18^{\circ} 38^{\prime} 36^{\prime \prime} \mathrm{N}\right.$ and $98^{\circ} 28^{\prime} 07^{\prime}$ 'W) by a commercial fishing vessel using bottom longlines, on April 30, 2010.

c. Description:The Gulf Smoothhound specimens were identified based on a number features, including their long, lean bodies that are flattened on the ventral side; a flattened head; a pointed, long rostrum (pre-oral length $6.2-7.2 \% \mathrm{TL}$ ); 5 pairs of gill slits, the fourth pair on the origin of the pectoral fins; large, oval eyes(2.6-3.2\% TL) with nictitating membranes at their base; the presence of small spiracles; the nostril width(1.5-1.6\% TL); the internarinal width $(2.1-2.9 \% \mathrm{TL})$; a wide mouth $(5.5 \% \mathrm{TL})$ with longer upper labial furrows (1.6-2\% TL); a limited number of small teeth arranged in a mosaic of several rows; and the presence of tricuspid dermal denticles between the pectoral and pelvic fins. Biometric data for the specimens are presented in Table 1 most measurements were within the ranges indicated by Compagno ${ }^{6}$ and Heemstra ${ }^{10}$ for this species.

d. Distribution: This species of shark is considered endemic to the Gulf of Mexico, with a distribution that extends from Panama City, Florida, USA to the Campeche bay, Mexico. ${ }^{5,8,10}$ Prior to this study, there have been no verified records of voucher specimens deposited in national reference collections; however, other researchers have previously discussed the species' presence in Mexican waters. $^{2}$ 
Table I Morphometric data for Mustelus sinusmexicanus [MSM] and Hexanchus nakamurai [HN] form Mexican waters. Boldface measurements are expressed as percentages of total length

\begin{tabular}{|c|c|c|c|}
\hline & MSM & MSM & HN \\
\hline Biometrics (mm) & ECOSC 747I & ECOSC 7472 & ECOSC 7414 \\
\hline Total length & 800 & 1092 & 896 \\
\hline Pre-caudal length & $6 \mid 4.0(76.7)$ & $935.0(85.6)$ & $570.0(65.6)$ \\
\hline Pre-narinal length & $32.0(4.0)$ & $52.0(4.7)$ & $13.0(1.5)$ \\
\hline Pre-oral length & $58.0(7.2)$ & $68.0(6.2)$ & $51.0(5.8)$ \\
\hline Pre-orbital length & $65.0(8.1)$ & $76.0(6.9)$ & $34.0(3.8)$ \\
\hline Pre-spiracle length & $40.0(5.0)$ & $55.0(5.0)$ & $96.0(10.9)$ \\
\hline Pre-gill length & $145.0(18.1)$ & $167.0(15.3)$ & $123.0(14.0)$ \\
\hline Pre-pectoral length & $160.0(20.0)$ & $210.0(19.2)$ & $146.0(16.6)$ \\
\hline Pre-pelvic length & $345.0(43.1)$ & $490.0(44.8)$ & 341.0 (38.9) \\
\hline Snout-ventral length & $382.0(47.7)$ & $475.0(43.5)$ & $366.0(41.8)$ \\
\hline Pre-dorsal length & $200.0(25.0)$ & $307.0(28.1)$ & 420.0 (47.9) \\
\hline Dorsal-caudal space & $298.0(37.2)$ & $453.0(4 \mid .5)$ & $99.0(11.3)$ \\
\hline Pre-anal length & $525.0(65.6)$ & $705.0(64.5)$ & $468.0(53.4)$ \\
\hline Pectoral-pelvic space & $168.0(21.0)$ & $310.0(28.3)$ & $143.0(16.3)$ \\
\hline Pelvic-anal space & $151.0(18.9)$ & $169.0(15.5)$ & $62.0(7.1)$ \\
\hline Anal-caudal space & $80.0(10.0)$ & $150.0(13.7)$ & $72.0(8.2)$ \\
\hline Pelvic-caudal length & $274.0(34.2)$ & $319.0(29.2)$ & $68.0(7.7)$ \\
\hline Eye length & $26.0(3.2)$ & $28.0(2.6)$ & $35.0(3.9)$ \\
\hline Eye height & $12.0(1.5)$ & $14.0(1.3)$ & $1.8(0.16)$ \\
\hline Inter orbital length & $58.0(7.2)$ & $73.0(6.7)$ & $72.0(8.2)$ \\
\hline Nostril width & I3.0 (I.6) & I7.0 (I.5) & $8.0(0.9)$ \\
\hline Internarinal width & $17.0(2.1)$ & $32.0(2.9)$ & $36.0(4.1)$ \\
\hline Anterior nasal fold & $5.0(0.6)$ & $7.0(0.6)$ & $7.0(0.8)$ \\
\hline Spiracle length & $5.0(0.6)$ & $7.0(0.6)$ & $3.0(0.3)$ \\
\hline Eye-spiracle length & $7.0(0.9)$ & $8.0(0.7)$ & $37.0(4.2)$ \\
\hline Mouth length & $57.0(7.1)$ & $85.0(7.8)$ & $103.0(11.7)$ \\
\hline Mouth width & $44.0(5.5)$ & $60.0(5.5)$ & $90.0(10.3)$ \\
\hline Upper labial furrow & $16.0(2.0)$ & $18.0(1.6)$ & $50.0(5.7)$ \\
\hline Lower labial furrow & I3.0 (I.6) & I5.0(I.4) & $21.0(2.4)$ \\
\hline First gill arch height & $25.0(3.1)$ & $41.0(3.7)$ & $85.0(9.7)$ \\
\hline Second gill arch height & $27.0(3.4)$ & $45.0(4.1)$ & $75.0(8.5)$ \\
\hline Third gill arch height & 25.0 & $37.0(3.4)$ & $63.0(7.2)$ \\
\hline Fourth gill arch height & $28.0(3.5)$ & $35.0(3.2)$ & $61.0(6.9)$ \\
\hline Fifth gill arch height & $17.0(2.1)$ & $22.0(2.0)$ & $58.0(6.6)$ \\
\hline Sixth gill arch height & - & - & $35.0(3.9)$ \\
\hline Head height & $90.0(11.2)$ & | 40.0 (I2.8) & $77.0(8.8)$ \\
\hline Head width & $150.0(18.7)$ & $190.0(17.4)$ & $94.0(10.7)$ \\
\hline Trunk height & $65.0(8.1)$ & $85.0(7.8)$ & $87.0(9.9)$ \\
\hline Trunk width & $73.0(9.1)$ & $113.0(10.3)$ & $78.0(8.9)$ \\
\hline Caudal peduncle height & $22.0(2.7)$ & $30.0(2.7)$ & $37.0(4.2)$ \\
\hline Caudal peduncle width & $12.0(1.5)$ & $18.0(1.6)$ & $24.0(2.7)$ \\
\hline Pectoral fin length & $72.0(9.0)$ & I59.0 (|4.6) & $105.0(11.9)$ \\
\hline Anterior margin of pectoral fin & II $5.0(14.4)$ & $170.0(15.6)$ & $107.0(12.2)$ \\
\hline Pectoral fin base length & $35.0(4.4)$ & $47.0(4.3)$ & $44.0(5.0)$ \\
\hline Pectoral fin height & $109.0(13.6)$ & 144.0 (I3.2) & $82.0(9.3)$ \\
\hline Pectoral fin inner margin & $60.0(7.5)$ & $75.0(6.8)$ & $49.0(5.6)$ \\
\hline Posterior margin of pectoral fin & $100.0(12.5)$ & $125.0(11.4)$ & $88.0(10.0)$ \\
\hline Pelvic fin length & $74.0(9.2)$ & $103.0(9.4)$ & $81.0(9.2)$ \\
\hline Anterior margin of pelvic fin & $67.0(8.4)$ & $75.0(6.8)$ & $40.0(4.5)$ \\
\hline Pelvic fin base length & $48.0(6.0)$ & $50.0(4.6)$ & $56.0(6.4)$ \\
\hline Pelvic fin height & $47.0(5.9)$ & $47.0(4.3)$ & $25.0(2.8)$ \\
\hline Pelvic fin inner margin & $40.0(5.0)$ & $55.0(5.0)$ & $23.0(2.6)$ \\
\hline Posterior margin of pelvic fin & $53.0(6.6)$ & $73.0(6.7)$ & $56.0(6.4)$ \\
\hline Outer clasper length & $65.0(8.1)$ & - & $27.0(2.9)$ \\
\hline Inner clasper length & $78.0(9.7)$ & - & $28.0(3.2)$ \\
\hline Clasper base length & $10.0(1.2)$ & - & $8.0(0.9)$ \\
\hline First dorsal fin length & $115.0(14.4)$ & $179.0(16.4)$ & $65.0(7.4)$ \\
\hline Anterior margin of first dorsal fin & $97.0(12.1)$ & $163.0(14.9)$ & $50.0(5.7)$ \\
\hline First dorsal fin base length & $87.0(10.8)$ & $130.0(\mid 1.9)$ & $49.0(5.6)$ \\
\hline First dorsal fin height & $64.0(8.0)$ & $103.0(9.4)$ & $26.0(2.9)$ \\
\hline Inner margin of first dorsal fin & $50.0(4.6)$ & $50.0(4.6)$ & $18.0(2.0)$ \\
\hline Posterior margin of first dorsal fin & $90.0(8.2)$ & $149.0(13.6)$ & $45.0(5.1)$ \\
\hline
\end{tabular}


Table Continued...

\begin{tabular}{|c|c|c|c|}
\hline & MSM & MSM & HN \\
\hline Second dorsal fin length & $86.0(10.7)$ & II $6.0(10.6)$ & - \\
\hline Anterior margin of second dorsal fin & $77.0(9.6)$ & $101.0(9.2)$ & - \\
\hline Second dorsal fin base length & $56.0(7.0)$ & $85.0(7.8)$ & - \\
\hline Second dorsal fin height & $49.0(6.1)$ & $64.0(5.8)$ & - \\
\hline Inner margin of second dorsal fin & $33.0(4.1)$ & $73.0(6.7)$ & - \\
\hline Posterior margin of second dorsal fin & $64.0(8.0)$ & $78.0(7.1)$ & - \\
\hline Anal fin length & $56.0(7.0)$ & $80.0(7.3)$ & $53.0(6.0)$ \\
\hline Anterior margin of anal fin & $49.0(6.1)$ & $68.0(6.2)$ & $23.0(2.6)$ \\
\hline Anal fin base length & $40.0(5.0)$ & $5 \mathrm{I} .0(4.7)$ & $37.0(4.2)$ \\
\hline Anal fin height & $25.0(3.1)$ & $45.0(4.1)$ & $14.0(1.6)$ \\
\hline Inner margin of anal fin & $20.0(2.5)$ & $33.0(3.0)$ & $13.0(1.5)$ \\
\hline Posterior margin of anal fin & $22.0(2.7)$ & $47.0(4.3)$ & $27.0(3.1)$ \\
\hline Dorsal margin of caudal fin & $422.0(52.7)$ & $614.0(56.2)$ & $282.0(31.0)$ \\
\hline Pre-ventral caudal fin margin & $73.0(9.1)$ & $82.0(7.5)$ & $63.0(7.2)$ \\
\hline Lower post-ventral caudal fin margin & $27.0(3.4)$ & $33.0(3.0)$ & $34.0(3.8)$ \\
\hline Upper post-ventral caudal fin margin & $77.0(9.6)$ & $85.0(7.8)$ & $160.0(18.2)$ \\
\hline Sub-terminal caudal fin margin & $27.0(3.4)$ & $34.0(3.1)$ & $44.0(5.0)$ \\
\hline Terminal caudal fin margin & $56.0(7.0)$ & $67.0(21.8)$ & $28.0(3.2)$ \\
\hline Terminal caudal lobe length & $172.0(2 \mid .5)$ & $254.0(23.3)$ & $64.0(7.3)$ \\
\hline Caudal fork length & $63.0(7.9)$ & $65.0(5.9)$ & $60.0(6.8)$ \\
\hline Distance between the origin of the first dorsal fin and the origin of the anal fin & $307.0(38.4)$ & $486.0(44.5)$ & $46.0(5.2)$ \\
\hline Distance between the origin of the first dorsal fin and the origin of the anal fin & $255.0(31.9)$ & $380.0(34.8)$ & $34.0(3.9)$ \\
\hline Distance between the origin of the second dorsal fin and the origin of the anal fin & $48.0(6.0)$ & $90.0(34.8)$ & - \\
\hline Distance between the origin of the second dorsal fin and the insertion point of the anal fin & $25.0(3.1)$ & $54.0(8.2)$ & - \\
\hline Caudal width space & $22.0(2.7)$ & $28.0(2.6)$ & $33.0(3.7)$ \\
\hline Caudal fork width & $22.0(2.7)$ & $28.0(2.6)$ & $33.0(3.7)$ \\
\hline Sex & Mature male & Female & Immature male \\
\hline Weight (g) & 1,100 & 3,500 & $\mathrm{I}, 560$ \\
\hline Gastric contents & Eviscerated & Eviscerated & Empty \\
\hline
\end{tabular}

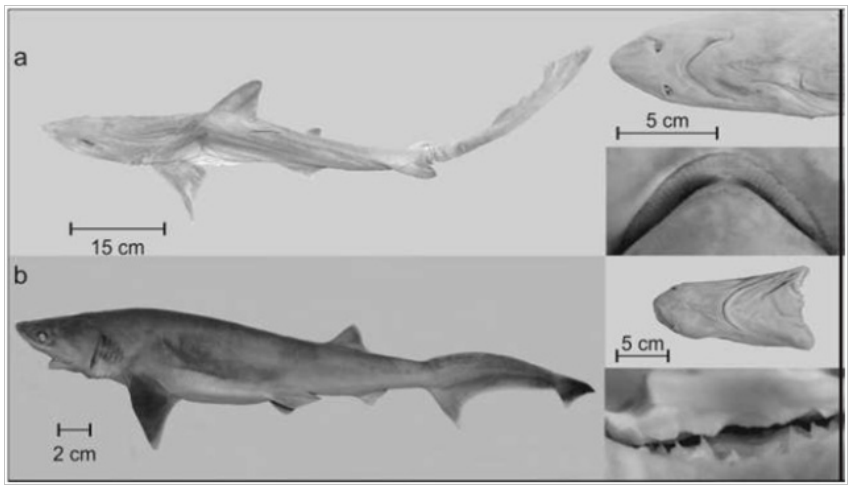

Figure I a) Mustelus sinusmexicanus, ECO-SC 747I-I (male specimen, 800 $\mathrm{mm} \mathrm{TL}, \mathrm{I}, \mathrm{l} 00 \mathrm{~g}$ ); and

b) Hexanchus nakamurai, ECO-SC 74I4 (male specimen, $896 \mathrm{~mm}$ TL, I,560 g) from the Gulf of Campeche,Mexico.

Order: Hexanchiformes

Family: Hexanchidae

Genus Hexanchus Rafinesque 1810

The genus Hexanchus is represented by 2 species with a circumglobal distribution, $, 5,7,89$ in Mexico's Atlantic and Pacific watersheds. ${ }^{2,14}$ Hexanchus nakamurai Teng 1962 (Figure 1b; Table 1)

a. Common name:Cazón ojigrande de seis branquias (Spa.); Bigeyed Sixgill Shark.

b. Materials examined:A sexually immature male specimen (ECOSC 7414; $896 \mathrm{~mm}$ TL, 1,560 g) was captured at a depth of $118.8 \mathrm{~m}$ by a commercial fishing boat using bottom longlines in the vicinity of Cayo Arcas (west of the Obispo Bank) near the Campeche Canyon (20 27'36”N and 92 12 '39'W) and southwest of the Yucatan Peninsula, Mexico, on May 11, 2012.

c. Description:The H. nakamurai specimen was identified based on the presence of 6 pairs of gill slits, the first longer (8.5\% TL) than the rest; a slim body; a flattened head with a long rostrum $(41.8 \%$ TL), the head is pointed and narrow relative to the robust body and head of the related $\mathrm{H}$. griseus Günther $1879 ;{ }^{14}$ relatively large eyes with a diameter $3.9 \%$ TL; a ventrally-located mouth; 5 large teeth in the mandible in a comb-like arrangement on each side of the symphyseal tooth (located in the center of each mandible); an upper jaw with nine teeth on each side, with a knife-like anterior apex; a single dorsal fin located in the space between the posterior part of the pelvic fin and the origin of the anal fin; a long $(11.3 \%$ TL) thin $(2.7 \% \mathrm{TL})$ caudal peduncle; and a deep notch in the upper lobe of the caudal fin. The specimen's biometrics are presented in Table 1; 68\% are within the ranges reported by Ebert et al. ${ }^{9}$ for the Sixgill Shark; the remaining $32 \%$ are within the range of variability in the specimens examined by those authors.

d. Distribution: The Sixgill Shark has a cosmopolitan distribution in the tropical and temperate oceans of the world (except the eastern Pacific). The species is distributed in the western Atlantic watershed from Florida to the West Indies, including the Gulf of Mexico and Caribbean Sea, to Venezuela and the Guianas, in the eastern Atlantic, from France to Morocco including the Mediterranean Sea; and in the southwest Indian Ocean, the Sea of Japan, Taiwan, and Australia. The species typically inhabits depths of 90-621 m, but is occasionally found on the surface or near the coast. ${ }^{5,6,7,8,9,15}$ On the Atlantic coast of Mexico, the species has been reported off the coast of Veracruz, ${ }^{2,16,17,18}$ although national ichthyologic reference collections previously lacked curated examples. 
e. General comments: This report of the Sixgill Shark, $H$. nakamurai Teng 1962 in Mexican waters is significant; the species' taxonomy had been challenged by its apparent morphological similarity ${ }^{19-22}$ with the Bigeye Sixgill Shark, $H$. vitulus Springer and Waller 1969; although they are genetically distinct. ${ }^{23,24,25}$ Based on a taxonomic study of both species, Ebert et al. ${ }^{9}$ determined that H.nakamurai should be recognized as a valid species that is widely distributed in the world's oceans in accordance to the re-description and designation of a neotype for this species (NMMBP 15835) supported by a specimen from Taiwan, as well as establishing $H$. vitulus as junior synonym. ${ }^{9}$ The specimen reported here is the first to be deposited in a national ichthyological collection.

\section{Discussion}

Due to our limited knowledge of the biology and ecology of these species, they have been assigned a conservation status of "data deficient" [sic] in the IUCN Red List of Threatened Species. ${ }^{15,26}$ Therefore, it is necessary to conduct basic studies of their population dynamics and other aspects of their basic biology in order to more accurately determine the current conservation status of their populations. ${ }^{5,11}$

In recent years, there has been an increase in the number of studies reporting new species of sharks, ${ }^{13}$ including new records of their presence and extensions to their distribution in Mexican waters. ${ }^{1}$ This situation highlights the fact that we have yet to fully explore the entirety of the country's cartilaginous fish, making further studies focusing on these species imperative.

\section{Acknowledgements}

We thank the crew of the fishing boat, La Perla del Golfo, and the artisanal fishery based out of the port of San Pedro for capturing these specimens. This project was partially funded by Grant No. 120925 awarded jointly by El Consejo Nacional de Ciencia y Tecnología (CONACyT) and the Tabasco State Government. AFGA is grateful for funding from the SNI-CONACyT, and the EDI and COFAA-IPN Programs. K Sullivan edited the English manuscript.

\section{Conflicts of interest}

None.

\section{References}

1. Ruiz-Campos G, Castro-Aguirre JL, Balart EF, et al. New specimens and records of chondrichthyan fishes (Vertebrata: Chondrichthyes) off the Mexican Pacific coast. Rev Mex Biodiv. 2010;81(2):363-371.

2. Espinosa-Pérez H, Castro-Aguirre JL, Huidobro-Campos L. IX Catálogo sistemático de tiburones (Elasmobranchii: Selachimorpha). Listados Faunísticos de México. Instituto de Biología-Universidad Nacional Autónoma de México, Distrito Federal, México. 2004.

3. Froese R, Pauly D. Fish Base. 2016.

4. Šanda R, De Maddalena A. Collection of the sharks of the Natural Museum in Prague- Part 1. Complete taxiderms and liquid preservations. J Nat Mus, Nat Hist Ser. 2003;172(1-4):61-70.

5. Castro JI. The sharks of North America. Oxford University Press, USA 2011.

6. Compagno L. Sharks. In: Carpenter K (Ed.), The living marine resources of the western central Atlantic. Introduction, mollusks, crustaceans, hagfishes, sharks, batoid fishes, and chimaeras. FAO Species Identification Guide for Fishery Purposes and American Society of Ichthyologists and Herpetologists, Special Publication 5, Rome. 2002; 1:357-600.
7. Ebert DA, Sthemann MFW. Sharks, batoids and chimaeras of the North Atlantic. FAO Species Catalogue for Fishery Purposes 7, Rome. 2013

8. Ebert DA, Fowler S, Compagno L. Sharks of the world. Wild Nature Press, UK. 2013.

9. Ebert DA, White WT, Ho HC. Redescription of Hexanchus nakamuraiTeng 1962, (Chondrichthyes: Hexanchiformes: Hexanchidae), with designation of a neotype. Zootaxa. 2013;3752:20-34.

10. Heemstra PC. A review of the Smooth-hound sharks (genus Mustelus, family Triakidae) of the western Atlantic Ocean, with descriptions of two new species and new subspecies. Bull Mar Sci. 1997;60(3):894-928.

11. Hurst R, Dando M. Shark trust: an illustrated compendium of shark, skates, rays and chimaera. Chapter 1: The British Isles and Northeast Atlantic, Part 2: Sharks. Wild Nature Press, UK. 2010.

12. Page LM, Espinosa-Pérez H, Findley LT, et al. Common and scientific names of fishes from the United States, Canada and Mexico. American Fisheries Society. 2013.

13. Castro-Aguirre JL, Antuna-Mendiola A, González-Acosta AF, et al. Una especie nueva del género Mustelus Linck, 1790 Chondrichthyes: Carcharhiniformes: Triakidae) de la costa suroccidental deBaja California Sur, México. Hidrobiológica. 2005;15:123-130.

14. Castro-Aguirre JL, Antuna-Mendiola A, González-Acosta AF, et al Primer registro del tiburón cañabota Hexanchus griseus (Bonnaterre, 1788) (Chondrichthyes: Selachiimorpha) en la costa occidental de Baja California Sur, México. Oceánides. 2003;18:39-41.

15. Ebert DA, Serena F, Mancusi C. Hexanchus nakamurai. IUCN Red List of Threatened Species. 2009.

16. Applegate SP, Espinosa-Arubarrena L, Menchaca-López L B, et al. Tiburones mexicanos. Secretaria de Educación Pública, Dirección General de Ciencia y Tecnología del Mar, México. 1979.

17. Applegate SP, Sotelo-Macías F, Espinosa-Arubarrena L. An overview of Mexican shark fisheries, with suggestions for shark conservation in Mexico. US Nat Mar Fish Serv Tech Rep. 1993;115:31-37.

18. Schadalach WL, Huidobro-Campos L, Espinosa-Pérez H. Peces marinos. In: González-Soriano E., Dirzo R, Vogt RC (Eds.), Historia natural de los Tuxtlas (pp. 463-471). Instituto de Biología UNAM, Instituto de Ecología UNAM, CONABIO, México, DF. 1997.

19. Adnet S. Biometric analysis of the teeth of fossil and recent hexanchid sharks and its taxonomic implications. Acta Paleontol Pol. 2006;51:477488

20. McEachran JD, Fechhelm, JD. Fishes of the Gulf of Mexico. Volume 1: Myxiniformes to Gasterosteiformes. University of Texas Press, USA. 2005 .

21. Springer S, Waller RA. Hexanchus vitulus, a new sixgill shark from the Bahamas. Bull Mar Sci. 1969;19(1):159-174

22. Taniuchi T, Tanikawa H. Hexanchus nakamurai, a senior synonym of $H$. vitulus (Elasmobranchii), with notes on its occurrence in Japan. Jap J Ichthyol. 1991;38:57-60.

23. Naylor GJP, Caira JN, Jensen K, et al. A DNA sequence-based approach to the identification of shark and ray species and its implications for global elasmobranch diversity and parasitology. Bull Am Nat Hist Mus. 2012;367:1-263.

24. Naylor GJP, Caira JN, Jensen K, et al. Elasmobranch phylogeny: a mitocondrial estimate based on 595 species. In: Carrier JC, Musick JA, Heithaus MR (Eds.), Biology of the sharks and their relatives CRC Press, USA. 2012;pp.3-69.

25. Tanaka K, Shiina $T$, Tomita $T$, et al. Evolutionary relations of Hexanchiformes deep-sea sharks elucidated by whole mitochondrial genome sequences. Biom Res Int. 2013;2013:1-11.

26. http://www.iucnredlist.org/details/60206/0. 